\title{
Research Study about the Role of Microfinance Institutions in the Development of Entrepreneurs
}

\author{
Sowmyan Jegatheesan, Sakthi Ganesh, and Praveen Kumar S.
}

\begin{abstract}
The Case Study is to have its Focus for entrepreneurs who want to run a business and yet can't afford a piece of equipment and merchandise. A research whereby providing equipment or merchandise to enable the project to run a self funding profitable project. In turn, A share in the project plus getting the full costs of the asset equipment or merchandise including an interest. So, direct seed finance is not needed to be put in a project. Microfinance is the provision that provides access to various financial services such as credit, savings, micro insurance, remittances, leasing to low-income clients including consumers and the self employed, who traditionally lack access to banking and related services. Its main objective is to provide a permanent access to appropriate financial services including insurance, savings, and fund transfer. As Micro finance becomes more widely accepted and moves into main stream, the supply of services to poor may also increase, improving the efficiency and outreach while lowering the costs.
\end{abstract}

Index Terms-Entrepreneurs, Funding for start-ups Microfinance, Seed funding.

\section{MicRofinANCE IN AFRICA}

Microfinance is the provision that provides access to various financial services such as credit, savings, micro insurance, remittances, leasing to low-income clients including consumers and the self employed, who traditionally lack access to banking and related services. Its main objective is to provide a permanent access to appropriate financial services including insurance, savings, and fund transfer. It is rather an important tool for the eradication of poverty. Poor will be able to deal with emergency and also make significant investment expenditures. As microfinance becomes more widely accepted and moves into main stream, the supply of services to poor may also increase, improving the efficiency and outreach while lowering the costs. Microfinance must involve the people themselves in examining the problems and creating solutions if it is to be sustainable with those upon whom development is targeted. To meet unsatisfied demand for financial services, a variety of microfinance institutions (MFIs) has emerged over time in Africa.

\section{A. Need of Microfinance in Africa}

- Only $6 \%$ of Africans borrow money to start a business where as $13 \%$ borrow to buy food.

- $50 \%$ of the population live with less than 1US\$ or less per day.

Manuscript received July 8, 2011; revised July 31, 2011.

Sowmyan Jegatheesan, Corresponding author. Tel.: +91 9842147452 ; E-mail address: jsowmyan@gmail.com.
- Africa's saving performance over time displays a downturn of saving rates over the past decades.

- High Interest rates make people harder to get credit.

B. Key Principles endorsed by CGAP and G8 Summit:

- Poor People need a variety of financial services not just loans.

- Microfinance is a powerful tool to fight poverty.

- Microfinance means building financial systems that serve the poor.

- Microfinance can pay for itself and must do so if it is to reach number of people.

- Microfinance is about building permanent local financial institutions

- Interest rate ceilings hurt poor people by making it harder for them to get credit.

- The role of government is to enable financial services not to provide them directly.

- Donor funds complete private capital not competes with it.

- The key bottleneck is the shortage of strong institutions and managers.

- Microfinance works best when it measures -and discloses - its performance.

C. Achievements of Microfinance in Africa

- 164 MFIs are the most important

- 500 MFIs belong to AFMIN (The Africa Microfinance Network)

- 700 Institutions With Respect to WAEMU (West African Economy Monetary Union)

- 5,328 Service points

- 10 million beneficiaries

\section{TYPES OF MFIS}

A. Banks

- Commercial Banks.

- Agricultural Credit Banks.

B. Project/State funds

- International aid Programs.

- Para-public organizations.

C. Informal Resources

- Family

- Traditional Savings

- Tontines

- Money Lenders 


\section{Microfinance}

- Credit \& Savings

- Direct Credit

Non Governmental Organizations(NGOs)

Performance of the Micro financial Institutions can be judged through their institutional financial viability and their outreach to the poor people. These performances could be influenced by the technical, political and the social factors to combine traditional and modern Micro-finance approaches.

\section{Microfinance-How to MaKe It SuCCESS In AfricA}

Many approaches have been used that ranges from the traditional group based systems to specialized lending by banks and funded by international Non-Governmental Organizations (NGO) financial intermediaries. Growing linkages between MFIs and the banking system in Africa appear to be mutually beneficial as MFIs rely on banks for a variety of services, including deposit facilities, liquidity management services, and emergency credit lines to cover cash shortfalls in some cases.

OSCAL (Office of the Special Coordinator for Africa and Least developed countries) developed four principles

- Pooling together people's resources

- Relying and building upon what people know

- Reinforcing microfinance to empower the African private sector

- Striving for efficiency, which include maintenance of tools and better working

In last twenty years Africa has made significant advances in understanding and providing financial services to better advance development and eradicate poverty. In 2006, government of Rwanda ordered to close the country's largest MFI's for bankruptcy due to gross mismanagement of funds and poor credit practices. In Benin, there are very small number bank branches (35 nationwide for population of 7 million) mostly concentrated around the capital city. Against this backdrop SLCs (Saving and Loan cooperatives) are the only MFIs that collect savings. In Guinea, reach of banking sectors is constrained by the limited number of deposit money banks, and credit is concentrated on largest domestic companies. MFIs have started to fill this gap. In Ghana, MFIs has a strong savings orientation and a greater role is played by Non Governmental Organizations (NGOs). Rural and Community Banks (RCBs), The Savings and Loans companies (S\&Ls) account for most of the microfinance activities. In Tanzania, only six percent of the population has a bank account. The primary sources of microfinance services are Savings and Credit Cooperatives (SACCOs), The National Microfinance Bank (NMB), Cooperative and Rural Development Bank (CRDB), Akiba Commercial Bank (ACB). In addition there are few regional and rural banks engaged in deposit-based microfinance operations which lack branch network.

\section{Methods in Micro FinAnCE}

To maintain a sustainable microfinance Institute various methods can be followed. Some of them are listed below.

\section{A. Community based Approach}

Many MFIs rely on local communities to support the development of MFIs, outside the formal banking sector. Traditional Community based cooperative groups such as village associations and local groups play a central role in the savings mobilization effort and expansion of other microfinance services. Microfinance seems to be rooted in local culture which is more participatory because clients are more ready to identify with and thus involve in making financial decisions and actions that shape their life.

- The Unique features involved are:

- It is simply and easily adapted to illiterate group members.

- Promotes group solidarity, learning and establish a vehicle for addressing community development issues.

- Doesn't rely on infusion of outside funds.

- Doesn't require physical infrastructure

\begin{tabular}{|c|c|c|}
\hline Country & $\begin{array}{l}\text { \% population } \\
\text { below poverty } \\
\text { line }\end{array}$ & $\begin{array}{ll}\text { GDP } & \\
\text { Per } & \text { Capita } \\
\text { (US\$) } & \\
\end{array}$ \\
\hline Angola & --- & 2058 \\
\hline Benin Botswana & 73.3 & 508 \\
\hline Burkina Faso & 55.5 & 5,846 \\
\hline Burundi & 71.8 & 391 \\
\hline Cameroon & 87.6 & 106 \\
\hline Cape Verde & 50.6 & 1,034 \\
\hline Chad & --- & 102 \\
\hline C.A.R & 64.0 & 561 \\
\hline Comoros & 84.0 & 339 \\
\hline Congo Congo & --- & 654 \\
\hline DR & --- & 1,273 \\
\hline Cote d'Ivoire & --- & 123 \\
\hline Djibouti & 48.8 & 900 \\
\hline Equatorial & --- & 894 \\
\hline Guinea & --- & 6,416 \\
\hline Eritrea & & \\
\hline Ethiopia & 53.0 & 220 \\
\hline Gabon & 77.8 & 157 \\
\hline Gambia & --- & 5,821 \\
\hline Ghana & 82.9 & 304 \\
\hline Guinea & 78.5 & 485 \\
\hline Guinea-Bissau & 40.0 & 350 \\
\hline Kenya Lesotho & --- & 190 \\
\hline Liberia & 58.3 & 547 \\
\hline Madagascar & 56.1 & 808 \\
\hline Malawi & --- & --- \\
\hline Mali Mauritania & 85.1 & 271 \\
\hline Mauritius & 62.9 & 161 \\
\hline Mozambique & 72.1 & 392 \\
\hline Namibia Niger & 63.1 & 605 \\
\hline Nigeria & 65.0 & 5,059 \\
\hline Rwanda & 74.1 & 335 \\
\hline Sao Tome e & 55.8 & 3,016 \\
\hline Principe & 85.8 & 244 \\
\hline Senegal & 92.4 & 752 \\
\hline Seychelles & 87.8 & 238 \\
\hline Sierra Leone & -- & 451 \\
\hline Somalia South & & \\
\hline Africa & 56.2 & 707 \\
\hline Swaziland & 50.0 & 8,209 \\
\hline Tanzania Togo & 74.5 & 216 \\
\hline Uganda & -- & --- \\
\hline \multirow[t]{6}{*}{ Zambia } & 34.1 & 5,109 \\
\hline & 77.8 & 2,414 \\
\hline & 89.9 & 316 \\
\hline & 32.2 & 358 \\
\hline & 37.7 & 303 \\
\hline & 87.2 & 623 \\
\hline
\end{tabular}




\section{B. Informal Methods for Financial Intermediation}

Various Informal traditional methodologies used by licensed MFIs have been instrumental in mobilizing savings from poor income households and giving them access to financial services.

\section{Group formation and Networking}

MFIs can use and support with regular meeting to emphasize group solidarity, discipline and consequent repayments. Some of them are commonly focused on women; they may also benefit other social groups. The efforts of MFIs to work through group schemes yield a wide range of benefits, developed by the Grameen Bank. MFIs that serve groups and communities could empower underprivileged social constituencies to encourage economic development and poverty reduction.

TABLE 2. AFRICAN COUNTRIES MFI BORROWERS

\begin{tabular}{|c|c|c|}
\hline Country & $\begin{array}{l}\text { \% population } \\
\text { below poverty } \\
\text { line }\end{array}$ & $\begin{array}{l}\text { Borrowers } \\
\text { from } \\
\text { MFIs } \\
\end{array}$ \\
\hline Angola & --- & 11,056 \\
\hline Benin Botswana & 73.3 & 110,728 \\
\hline Burkina Faso & 55.5 & 0 \\
\hline Burundi & 71.8 & 136,888 \\
\hline Cameroon Cape & 87.6 & 10,272 \\
\hline Verde Chad & 50.6 & 86,289 \\
\hline C.A.R & --- & 0 \\
\hline Comoros & 64.0 & 15,348 \\
\hline Congo Congo & 84.0 & 2,176 \\
\hline DR & --- & --- \\
\hline Cote d'Ivoire & --- & 2,719 \\
\hline Djibouti & --- & 196,244 \\
\hline Equatorial & 48.8 & 5,117 \\
\hline Guinea Eritrea & --- & --- \\
\hline Ethiopia & --- & --- \\
\hline Gabon & & \\
\hline Gambia & 53.0 & --- \\
\hline Ghana Guinea & 77.8 & $1,795,559$ \\
\hline Guinea-Bissau & --- & 65 \\
\hline Kenya Lesotho & 82.9 & 574 \\
\hline Liberia & 78.5 & 213,341 \\
\hline Madagascar & 40.0 & 99,105 \\
\hline Malawi & --- & --- \\
\hline Mali Mauritania & 58.3 & 857,953 \\
\hline Mauritius & 56.1 & --- \\
\hline Mozambique & --- & 2,711 \\
\hline Namibia Niger & 85.1 & 28,815 \\
\hline Nigeria & 62.9 & 60,536 \\
\hline Rwanda & 72.1 & 194,649 \\
\hline Sao Tome e & 63.1 & -- \\
\hline Principe Senegal & 65.0 & --- \\
\hline Seychelles Sierra & 74.1 & 49,327 \\
\hline Leone Somalia & 55.8 & --- \\
\hline South Africa & 85.8 & 97,495 \\
\hline Swaziland & 92.4 & 404,683 \\
\hline Tanzania Togo & 87.8 & 39,000 \\
\hline \multirow{12}{*}{$\begin{array}{l}\text { Uganda } \\
\text { Zambia }\end{array}$} & --- & 0 \\
\hline & & \\
\hline & 56.2 & 206,125 \\
\hline & 50.0 & --- \\
\hline & 74.5 & 10,318 \\
\hline & --- & --- \\
\hline & 34.1 & 636,387 \\
\hline & 77.8 & 14,430 \\
\hline & 89.9 & 238,613 \\
\hline & 32.2 & 88,964 \\
\hline & 37.7 & 207,200 \\
\hline & 87.2 & 14,354 \\
\hline
\end{tabular}

\section{Microfinance}

If Microfinance has a sustainable impact on poverty eradication, then it must level up as into starting a private sector of entrepreneurs who function in formal economy. It can support inventiveness for direct supply and market linkages to small and medium businesses that targets entrepreneurs in non-traditional, low volume but high value added products in potential role growth areas of economy.

\begin{tabular}{|c|c|c|}
\hline Country & $\begin{array}{c}\text { \% population } \\
\text { below poverty } \\
\text { line }\end{array}$ & $\begin{array}{c}\text { Savers from } \\
\text { MFIs }\end{array}$ \\
\hline Angola & --- & 27,042 \\
\hline Benin Botswana & 73.3 & 54,760 \\
\hline Burkina Faso & 55.5 & 0 \\
\hline Burundi & 71.8 & 515,747 \\
\hline Cameroon & 87.6 & 2,796 \\
\hline Cape Verde & 50.6 & 360,738 \\
\hline Chad & --- & 0 \\
\hline C.A.R & 64.0 & 53,118 \\
\hline Comoros & 84.0 & 34,724 \\
\hline Congo Congo & --- & --- \\
\hline DR & --- & 20,398 \\
\hline Cote d'Ivoire & --- & 569,200 \\
\hline Djibouti & 48.8 & 17,196 \\
\hline Equatorial & --- & --- \\
\hline Guinea & --- & --- \\
\hline Eritrea & & \\
\hline Ethiopia & 53.0 & --- \\
\hline Gabon & 77.8 & 856,903 \\
\hline Gambia & --- & 1,578 \\
\hline Ghana & 82.9 & 8,825 \\
\hline Guinea & 78.5 & 361,323 \\
\hline Guinea-Bissau & 40.0 & 65,470 \\
\hline Kenya Lesotho & --- & --- \\
\hline Liberia & 58.3 & $3,142,155$ \\
\hline Madagascar & 56.1 & -- \\
\hline Malawi & -- & 0 \\
\hline Mali Mauritania & 85.1 & 157,806 \\
\hline Mauritius & 62.9 & 147,405 \\
\hline Mozambique & 72.1 & 382,233 \\
\hline Namibia Niger & 63.1 & --- \\
\hline Nigeria & 65.0 & --- \\
\hline Rwanda & 74.1 & 91,567 \\
\hline Sao Tome e & 55.8 & --- \\
\hline Principe & 85.8 & 141,372 \\
\hline Senegal & 92.4 & 181,610 \\
\hline Seychelles & 87.8 & 39,563 \\
\hline Sierra Leone & -- & 0 \\
\hline Somalia South & & \\
\hline Africa & 56.2 & 524,428 \\
\hline Swaziland & 50.0 & --- \\
\hline Tanzania Togo & 74.5 & 6,264 \\
\hline Uganda & -- & --- \\
\hline Zambia & 34.1 & 837,700 \\
\hline & 77.8 & 0 \\
\hline & 89.9 & 0 \\
\hline & 32.2 & 318,952 \\
\hline & 37.7 & 614,494 \\
\hline & 87.2 & \\
\hline
\end{tabular}

\section{E. Prioritisation of Operational Efficiency}

If MFIs are to have a better impact on poverty eradication they must be capable, financially viable institutions that can develop the financial leverage to extend outreach at a sustainable level. Key Principles include

- Target the poorest of the poor.

- Mobilize the Savings.

- Charge less interest rates that only cover Operational 
- Costs.

- Market Research.

- Modernizing and Spread out Operations.

- Utilizing Volunteer Staff.

- Prioritizing Women.

- Develop Monitoring and Assessment Tools.

- Investing in Training.

- Tackle the problems.

- Utilize Pre-Existing Support Organizations.

- Evade External Dependency.

\section{FINANCIAL NEEDS OF ENTREPRENEURS IN AFRICA}

Most of the Africans lack the understanding of what it would take to successful entrepreneurs. They lack necessary technical management skills and confidence. They lack personal ambition and willingness for fear of sharing ownership and failed to form partnership. Some basic tips to the entrepreneurs that helps in the effective handling of microfinance activities. These will help to expand the scope that scale up through state to the global community.

- Acknowledge and Empower African People.

- Set up Realistic Expectations.

- Perform Research.

- Approve Plans Supporting Microfinance Infrastructure.

- Start a Supportive Legal Environment.

- Develop Monitoring and Assessment Tools.

- Change the Public Structures.

- Encourage Microenterprise Initiatives.

- Reinforce Staff Training.

- Utilize pre-existing Institutions such as Postal Savings Banks (PSB).

- Encourage Networking and Cooperation.

On part of African government, rather than viewing local entrepreneurs and capitalists as social threats and passive owners pounded by external forces, they should consider them as potential creators of wealth and transformers of the same environment in which they fight to exist. Government leaders should adopt national development strategies that generate an investment environment conductive to long term business activities. This type of environment can attract a flow of better educated professionals, administrators and technicians into private business.

In Africa, Entrepreneurs:

- Must set high Standards of Personal achievements and strive to attain them.

- Should maintain considerable ingenuity and possess business skills.

- Should take tremendous risks in experimenting with new ideas.

- Should be ready to move from the "Profit for self and family" attitude to "Profit for business growth" philosophy.

- Must utilize higher levels of technology with proper training and specialization.

- Must obtain greater degrees of organizational competence and delegate responsibility.

- Must establish more impersonal systems of control.

- Must encourage wide range marketing.
Some of the elements to be considered for a start up of an Enterprise:

- The nature of the enterprise must be appropriate in economic, social and environmental terms.

- Enterprise Policies must be flexible to facilitate local circumstances.

- It should involve features that go beyond traditional enterprise policy.

- They should have special policies and programs for the development and channeling of entrepreneur talent.

\section{PRoBlems Faced By the ENTREPRENEURS}

- Technical Assistance

- High Costs

- Few Support Institutions

- Entrepreneurial Attitude

- Tendency towards isolation.

- Lack of organization and integration.

- Financing

- Limited access to financing, both for startup and expanding

- Lack of endorsement and guarantees

- Policy and Enabling Environment

- Excessive regulations and formalities

- Political and economic instability

- Market

- Problems in acquisition of inputs

- Lack of Expertise in domestic and external marketing.

\section{SOlutions For THE PROBlems FACED}

- National trainers/counselors can be prepared.

- Implementation of successful experiences

- Development of institutions for support services of technical kind

- Entrepreneurial training and preparation of young people

- Support to and cooperation with existing business/entrepreneurial

- Association-grouping

- Identification of specific obstacles

- Recommendations for change and environment within these areas

- Adaptation of legal framework

- Vertical Integration

- Information links, regional and international links

\section{REFERENCES}

[1] United Nations Organization, Micro Finance Model.

[2] CGAP - G8 - Microfinance Policy Document.

[3] The International Conference Organized By Microfinance African Institutions Network.

[4] Microfinance Council - Performance Standards for MFIs.

[5] Diagnostic to action: microfinance in Africa.

[6] State-of-the-sector report bringing financial services to Africa's poor.

[7] Micro-entrepreneurs: Motivations Challenges and Success Factors.

[8] Uganda entrepreneurs: Why are they in business? Journal of Small Business Strategy.

[9] Ghanaian and Kenyan entrepreneurs: Analysis of their motivations, success characteristics and problem. Journal of Developmental Entrepreneurship.

[10] Finance and small and medium-sized enterprises in developing countries. Journal of Developmental Entrepreneurship. 